



overleaf: C. G. Jung: Bollingen, 1959 


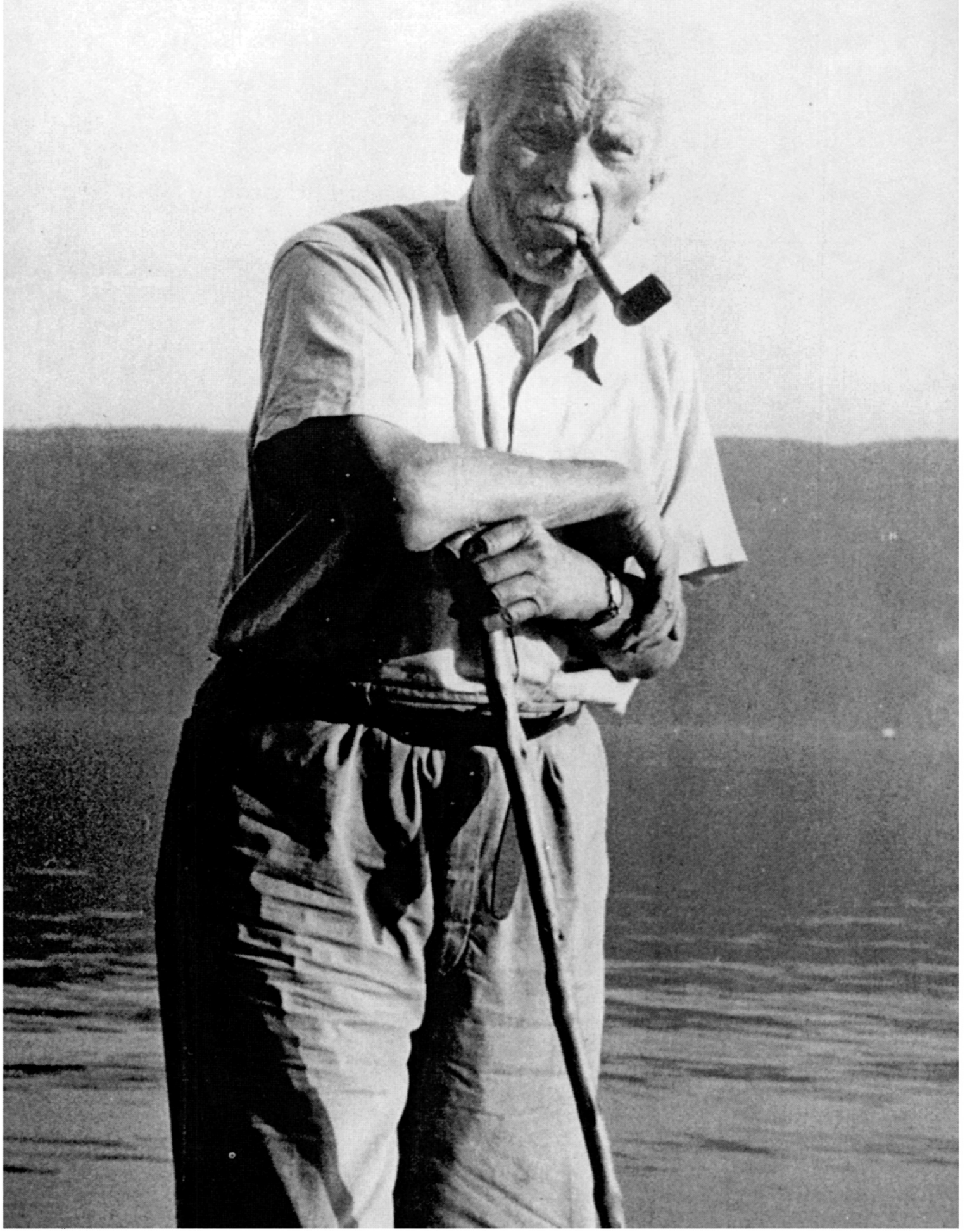




\section{C.G.JUNG LETTERS}

selected and edited by GERHARD ADLER

in collaboration with ANIELA JAFFÉ

translations from the German by $\quad$ R. F. C. HULL

in two volumes $\quad 2: 1951=1961$

BOLLINGEN SERIES XCV : 2 PRINCETON UNIVERSITY PRESS 
Copyright (C) $1953,1955,1961$, $1963,1968,1972,1972,1974,1975$ by

Princeton University Press, Princeton, New Jersey

\section{THIS TWO-VOLUME WORX IS THE \\ NINETY-FIFTH IN A SERIES OF BOOKS SPONSORED BY BOLLINGEN FOUNDATION}

The letters in these two volumtes were published, with smme variations, in C. C. Jung: Briefe, edited by Aniela Jaffc, in collaboration with Gerhard Adler, threc volumes, (c) Walter-Verlag AG, Olten (Switzerland), 1972 and 1973. The following letters have been previously published either in Jung's original English or in R.F.C. Hull's translation. (Copyright in the letters prefixed by an asterisk has been assigned to Princeton University Press.) - To Lonis S. London, 24 Sept. 26, in London,. Mental Therapy: Studies in Fifty Cases, copyright, 1937, by Lotis S. London; * to Mary Foote, 19 Mar. 27, 28 Mar. 33. 18 Dec. 29. 12 July 37, in Spring, 1974, copyright (C) 1974, The Analytical Psychology Club of New York Inc.; to James Joyce, :7 Sept. 32, in Riclard Ellmann, James Joyce, (C) by Richard Ellnann, 1959; " to Sally M. Pinckncy, 30 Sept. 48, in the Bulletin of the Analytical Psychology Club of New York, $X$ (Sept. 1948), copyright $194^{8}$ by the Analytical Psychology Club of New York Inc.; to Emanuel Maier, ${ }_{4}$ Mar. 50, in The Psvchoanalytic Review, vol. $50(1963)$. copyright (C), 1963, by the National Psychological Association for Psychoanalysis, Inc.; to Ernest Jones, 22 Feb. 52, 19 Dec. 53, and to

K. R. Eissler, 20 July 58, in The Freud/Jung Letters, copyright (C) 1974 by Princeton University Press (for Sigmund Freud Copyrights Ltd. and Erbengemeinschaft Prof. Dr. C. G. Jung); * to Upton Sinclair, 3 Nov, 52. 7 Jan. 55, in New Republic, copyright 1953 and 1955 in the USA by New Republic, Inc.; to James Kirsch, 18 Nov. 52, in Psychological Perspectives, the letter being copyright (c) 1972 by Princeton University Press; to Carl Seelig, 25 Feb. 53; A. M. Hubbard, 15 Feb. 55; Theodor Bovet, 9 Nov. 55; Anon., 19 Nov. 55; the Earl of Sandwich, 10 Aug. 60, in Spring, 1971, the letters being copyright (C) 1971 by Princeton University Press; to Patricia Graecen, 29 June 55, in Patricia Hutchins,

lames Joyce's World, Methuen, 1957, and in James Joyce, (c) by Richard Ellmann, 1959; to Simon

Doniget, Nov. 55, in Pastoral Psychology, VI:60 (Jan. 1956), copyright 1955 by Pastoral Psychology

Press; to H. L. Philp, 12 June 57, in Plulp, Jung and the Problem of Evil, (C) H. L. Philp, 1958; to John Trinick, 15 Oct. 57, in Trinick, The Fire-Tried Stone, (c) John Trinick, 1967; to Gustav Steiner, 30 Dec.

57. (the present tr. by R.F.C. Hull with minor variations), in the editor's introduction to Memories,

Dreums, Reflections by C. G. Jung, recorded and edited by Aliela Jaffé, copyright (C) 1961, 1962, 1963

by Random House, Inc., and published by Pantheon Books, a division of Randoin House, Inc.; " to Joseph R. Rychlak, 27 Apr. 59, in Rychlak, A Philosophy of Science for Personality 'Theory, copyright (c) 1968 by Joseph R. Rychlak; ${ }^{\circ}$ to Valentine Brooke, 16 Nov. 59, (partially) in Aniela Jaffe, The Myth of Meaning, (C) 1971 by the C. G. Jung Foundation; * to A. D. Cornell, 9 Feb. 60 , (in tr. by Hildegard Nagel), in Spring, 1961, copyright 1961 by the Analytical Psychology Club of New York Inc.; to Miguel Serrano, 31 Mar. 60, 14 Sept. 60, in C. G. Jung and Hermann Hesse, (c) Miguel Serrano 1966; to Melvin J. Lasky, 19 Oct. 60, in Encounter, Feb. 1961 , (C) 1961 by Encounter Ltd.; to Edward Thornton, 1 Dec. 60 , The Diary of a Mystic, (C) George Allen \& Unwin Ltd., 1967; * to William G. Wilson, 30 Jan. 61, in two issues of AA Grapevine, (C) 1963 and 1968 by AA Grapevine.

Library of Congress Catalogue Card

Number: $74^{-166} 37^{8}$

ISBN $0.691 .097^{24} \cdot 0$

Fifth printing, 2020

MANUFACTURED IN

THE U.S.A.

ISBN-13: 978-0-691-09724-4 (cloth) 